\title{
What's yours is mine and what's mine is mine? Re-thinking intellectual property and research ethics from the experience of the Purhépecha community of Cherán
}

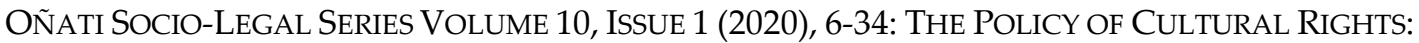 \\ State Regulation, SOCial CONTESTATION AND CULTURAL DiVERSITY \\ DOI LINK: HTTPS://DOI.ORG/10.35295/OSLS.IISL/0000-0000-0000-1102 \\ RECEIVED 05 MAY 2018, ACCEPTED 12 FEBRUARY 2019
}

\author{
LUCERO IBARRA ROJAS* (iD) \\ EZEQUIEL ESCOBEDO OSORIO* ID \\ FOGATA KEJTSITANI
}

\section{Abstract}

Intellectual property and cultural policy are essential to the practice of cultural rights, however, in both legal frameworks, indigenous peoples have often found that the state has little consideration for their voices and their world views. In contrast, though no more representative of indigenous perspectives, the social sciences, while engaging with indigenous voices, have often treated them as a source to be appropriated with disregard of their rights and agency. Through an activist and collaborative methodology that includes the concerns of a wide group of indigenous and non-indigenous persons, this article explores how the oral history project of the Fogata Kejtsitani in the Purhépecha community of Cherán, Mexico, contributes to discussions on the appropriation and dissemination of culture. This community has managed the recognition of their right to autonomy, and in so doing, has founded a continuous process of law creation, on which Kejtsitani takes part.

\footnotetext{
This article is part of the cultural heritage of the Purhépecha community of Cherán.

We wish to thank Leire Kortabarria for her invaluable and diligent work with OSLS, as well as the reviewers of this article for their comments and contributions.

* Professor-Researcher at the Legal Studies Department of the Centre for Research and Teaching in Economics (CIDE). PhD in Law and Society from the University of Milan, M.A. in the Sociology of Law from the Oñati International Institute for the Sociology of Law (IISL) and Law Degree from the Universidad Michoacana de San Nicolás de Hidalgo. She is a member of the Network of Sociology of Law in Latin America and the Caribbean and the Collective Emancipations of Critical Studies of Law and the Humanities. Current Secretary and Board Member of the Research Committee on the Sociology of Law (RCSL) of the International Sociological Association (ISA). Contact details: Carr. México-Toluca 3655, Lomas de Santa Fe, C.P. 01210 Ciudad de México, México. Email address: lucero.ibarra@cide.edu

* Member of the litigation department at the Mexican law firm Calderon \& de la Sierra. Law Graduate at the Centre for Research and Teaching in Economics (CIDE). Contact details: Avenida Santa Fe 546, Lomas de Santa Fe, C.P. 05349, Ciudad de México, México. Email address: Ezequiel.escobedo@cide.edu
} 


\section{Key words}

Indigenous peoples; research ethics; intellectual property; autonomy; oral history

\section{Resumen}

La propiedad intelectual y la política cultural son esenciales para la práctica de derechos culturales, sin embargo, en ambos marcos jurídicos los pueblos indígenas frecuentemente han encontrado que el Estado tiene poca consideración por sus voces y cosmovisiones. En contraste, aunque sin ser más representativo de las perspectivas indígenas, las ciencias sociales que se han relacionado con voces indígenas, frecuentemente las han tratado como una fuente para ser apropiada, descartando sus derechos y agencia. A través de una metodología activista y colaborativa que incluye las inquietudes de un amplio grupo de personas indígenas y no-indígenas, este artículo explora cómo el proyecto de historia oral de la Fogata Kejtsitani en la comunidad Purhépecha de Cherán, México, contribuye a las discusiones sobre la apropiación y diseminación de la cultura. Esta comunidad ha logrado el reconocimiento de su derecho de autonomía y, al hacerlo, ha fundado un proceso continuo de creación de derecho del cual Kejtsitani también forma parte.

\section{Palabras clave}

Pueblos indígenas; ética en la investigación; propiedad intelectual; autonomía; historia oral 


\section{Table of contents}

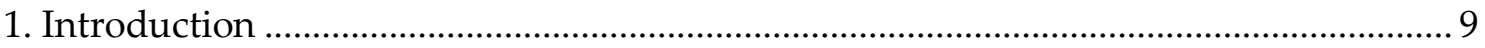

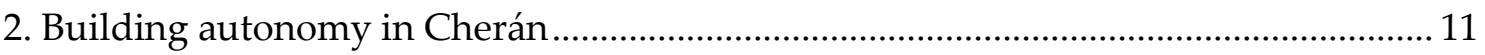

3. Transforming a challenge into an opportunity: why and how to establish a dialogue about intellectual property and research ethics in Kejtsitani.....

4. Building on Cherán's autonomy and institutions: how Kejtsitani contributes to the

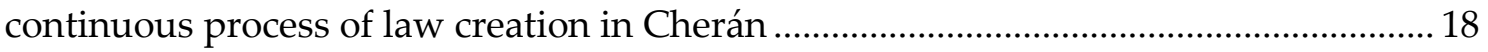

5. Research ethics and intellectual property from Cherán .................................................. 21

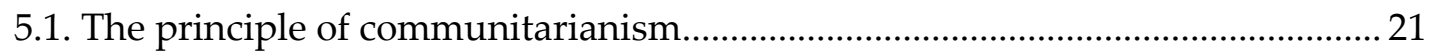

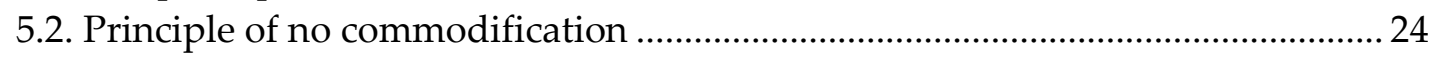

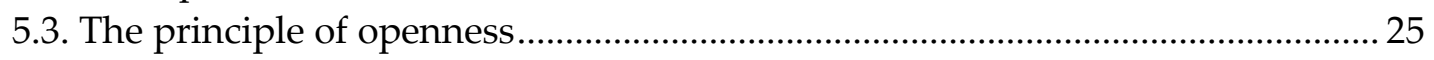

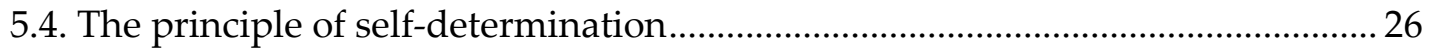

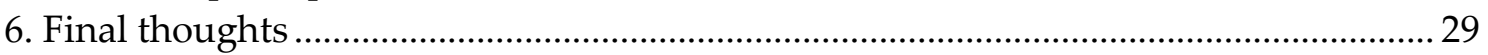

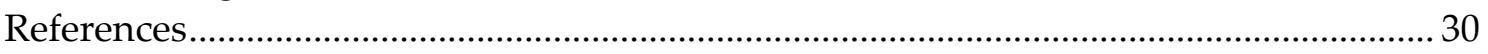




\section{Introduction}

Intellectual property and cultural policy are essential to the practice of cultural rights, however, inf both legal frameworks, indigenous peoples have often found that the state has little consideration for their voices and their world views. In contrast, though no more representative of indigenous perspectives, the social sciences have often treated the voices of indigenous peoples as a source to be appropriated with entire disregard of their rights and agency. The problem is hardly new: dispossession began with colonization and was later perpetuated by the law, which maintained the subordination of indigenous peoples after territories gained their independence. The explorers would come to study the natives of some "newly discovered land", playing the undercover agent or, even worse, the friend who would gain their trust, and learn their beliefs and their myths, only to exploit the interactions as "scientific" discoveries. The explorer, now turned scientist, would appropriate indigenous knowledge because, as a result of the non-person status attributed to natives of the land, this knowledge, just like the land, was deemed newly discovered. As part of the colonial narrative, indigenous peoples were ascribed beliefs instead of science, culture, and law (Fitzpatrick 1998). This story endures. Researchers continue to learn from indigenous communities and, aided by intellectual property laws that suit their interests, can still claim ownership over indigenous production while the communities cannot. These researchers can go back to their universities, making use of their voice to disseminate their findings, while the community may never hear from them again. Communities that come into contact with researchers often find that extractivist practices go beyond the extraction of their natural resources to the extraction of their knowledge and culture as well.

This is a problem of research ethics that is embedded in the intellectual property rights system. Indeed, one of the many objections raised against the intellectual property system is its incompatibility with indigenous cultural expressions. Studies on traditional knowledge have long asserted that the notions of innovation, as separate from tradition; and the notion of individual genius, as the legitimizing argument to establish an economic monopoly, do not characterize indigenous creation that is based on tradition and developed collectively (e.g. Dommann 2008, Kongolo 2008, Antons 2009). The problems of traditional knowledge and traditional cultural expressions evidence the obstacles that some indigenous peoples may still experience to asserting intellectual property rights over their cultural products, but also to stopping others, who can comply with the formal requirements, from unfairly asserting rights and potentially excluding indigenous creators. Therefore, the processes of globalisation and the dangers of misappropriation, biopiracy and unfair commercialisation of indigenous cultural expressions are widely documented in instances of traditional medicine, indigenous arts and other indigenous creations (e.g., Kur and Knaak 2004, Graber and Burri-Nenova 2008, Tobin 2009). What is perhaps much less discussed is how academic practices also renew this injustice by turning the experiences and knowled ge of communities into work claimed by a single author as her own. This, however, is only the nominative aspect, and sometimes the more naturalized, of practices that we have hidden under the veil of methodological objectivity, and which often only reify the academic voice in its hegemony. In this sense, these concerns are embedded in what has been called "cannibalizing epistemes" (Teubner and Fischer-Lescano 2008) of intellectual property, that not only put forward a specific episteme, but also deny others. 
Current Mexican regulation scarcely deals with these issues. Mexico's legislation on intellectual property is expressed in two different pieces of legislation: the Federal Law of Industrial Property and the Federal Law on Rights of Authors. Only the latter addresses indigenous creations through a special section: Title VII. On the Author's Rights over National Symbols and Popular Cultures' Expressions. In this legislation expressions of popular culture are defined as those in which no individual author can be recognized. Instead, this section only gives "communities or ethnic groups" "moral rights" - the right to be named as the source of the cultural expression, and to oppose any alteration which may damage their reputation. The "patrimonial rights" that give an author a right to economic gain are not contemplated in this law (Ibarra 2010, pp. 33-35). This may answer matters of misrepresentation, and even some misappropriation concerns put forward by indigenous communities in other contexts (as explored by Lucas-Schloetter 2004, pp. 261-262), but it does not address the possibility of appropriation of what is being constantly created, nor does it include a provision by which communities can define the rules for access to their cultural processes.

Some solutions have been brought forward, mainly by academic agents, though they have been insufficient in addressing the needs of indigenous communities. Teubner and Fisher-Lescano (2008), for example, recognise that a substantive global approach is insufficient to the question of traditional knowledge, and that the law of the communities should be considered, but they end up considering this an impossibility due to the incompatibility of rationale between different legal systems. A common practical alternative has been to create catalogues of traditional knowledge, a practice that tends to bring the logics of academia to the field of traditional knowledge through the documentation of knowledge and creation. Further, this is only a preventive strategy in that it helps to stop others who may wish to register community knowledge, but gives no rights to the communities themselves. The upside is the documentation itself, which can provide further tools for conservation in the sense that the community could have further tools for the education and the dissemination of said knowledge. The downside, however, lies in the introduction of static elements that cannot respond the continuous process of creation and discovery. While many options can be devised to respond to the limitations that make intellectual property a cannibalizing episteme, we suggest that more effective alternatives can be found within the voices and social processes of the communities of creators that remain outside the scope of its more orthodox understandings. In fact, communities like the San peoples, a first nation in southern Africa, have created a code of ethics for researchers that researchers must follow to do research with them (South African San Institute 2017).

This article explores how the challenge to reverse traditional power dynamics in intellectual property has been undertaken by the Fogata ${ }^{1}$ Kejtsitani in the indigenous community of Cherán (México). Kejtsitani is constituted by a group of people, both from within the community and from outside it, who are involved in an oral history project. As part of its activities, Kejtsitani has developed a discussion over appropriation and dissemination of culture that constitutes a great contribution to intellectual property and research ethics. This article explores this experience based on a collaborative and activist ${ }^{1}$ Fogata means "bonfire". However, we keep the word in Spanish to indicate the configuration of a form of
organisation that will be further presented in this article. 
research methodology in which the authors collaborated within the Fogata in the development of intellectual property and research guidelines meant to express commitments with communitarian values and Cherán's self-determination. This project could be characterised as a decolonisation of intellectual property, by addressing how social relations and interests that are at the core of intellectual property can in fact be thought of from a perspective deeply connected with the processes of an indigenous autonomy; even though there was no particular inclination for a specific decolonial theory guiding the concerns here expressed. The diversity of participants that have engaged in this discussion, however, does show that conceiving the efforts to rethink legal forms can be, and indeed should be, nurtured by a diversity of voices and concerns.

We begin with a description of the political and legal context of Cherán and Kejtsitani, which bears some particularities that are essential to the way the project was developed. In the following section, we describe the political processes that Kejtsitani developed both in relation with the community, and in consideration of its own identity, through the exercise of creating intellectual property and research guidelines. Afterwards we explain the main principles developed by Kejtsitani and how they are expressed in a potential agreement with the University of Guanajuato (UG). These principles not only challenge predominant understandings of intellectual property and research ethics, but also portray different ways of conceptualizing law and of expressing political commitments.

\section{Building autonomy in Cherán}

The right to self-determination of indigenous peoples is regulated both in the Mexican Constitution and in international treaties. Article 2 of the Mexican Constitution establishes: "This Constitution recognizes and guarantees the right of indigenous peoples and communities to free determination and, consequently, to autonomy". In the international sphere, this is recognized in Article 3 of the United Nations Declaration on the Rights of Indigenous Peoples and in the Article 1 of the International Covenant on Civil and Political Rights. Though perhaps the most relevant international instrument for the defense of the rights of indigenous peoples is the International Labor Organization's (ILO) Indigenous and Tribal Peoples Convention 169. In Mexico, the right to self-determination was relevant to the Superior Chamber of the Electoral Tribunal, in the case Trial for the Protection of the Political-Electoral Rights of the Citizen, corresponding to file SUP-JDC-9167/2011. In this case, the court analyzes the right to selfdetermination of the indigenous people of Cherán in relation to carrying out elections under their customs and habits. ${ }^{2}$ Indeed, the indigenous community of Cherán in the state of Michoacán, México, acquired visibility in the political landscape of the country when it became the first indigenous municipality that managed the recognition of their right to autonomy. This led to the community being governed by its own customary forms and authority, and to a continuous process of law creation (Aragón 2017).

This electoral trial is a ground-breaking precedent in the Mexican legal system and part of a larger mobilization process in Cherán. On the $15^{\text {th }}$ of April 2011, the community of

\footnotetext{
${ }^{2}$ Although the Mexican constitution acknowledges indigenous law as indigenous normative systems, the nomination as "customs and habits" was used by the Superior Chamber of the Electoral Tribunal and has been adopted by the people of Cherán to refer to their own electoral organisation.
} 
Cherán rose against the organized crime that, colluding with the local government, was extinguishing their forest. ${ }^{3}$ The tala-montes ${ }^{4}$ were devastating the forests of Cherán, cutting down that which sustains hundreds of families, while the community suffered the violence of the organized crime that carried out these activities under the protection of the government. Led by the women, the community detained the tala-montes, while the local authorities deserted them. A confrontation with the organized crime followed, and the community started a process of resistance. It also organized a local government to defend itself, as well as to administrate the community in the absence of the authorities. In the midst of their resistance, community members believed that political parties were a source of corruption and disagreement among the people in the community, and decided not to participate in the ordinary political process, and not to allow it in the community. On June 6, 2011, they presented a petition to the Electoral Institute of Michoacán to carry out elections under the customs and habits of the indigenous people of Cherán. This local authority, however, failed to comply with the request, and on September 9, 2011, the General Council of the Electoral Institute of Michoacán issued agreement GC-38/2011 that stated: the institute lacks powers to resolve the petition. The community started a legal process, accompanied by a group of lawyers graduated from the local Universidad Michoacana de San Nicolas de Hidalgo (UMSNH) and who were working or studying in this institution at the time although their actions were not linked to it. This group of lawyers would later face a process of separation from said university and become the Collective Emancipations (Aragón 2018). On September 15, 2011, members of indigenous community promoted an action per saltum for a Citizen's Political-Electoral Rights Protection (JDC in Spanish) which was later "attracted" 5 by the Superior Chamber. One of the main problems that the court considered was that indigenous peoples had only been recognized for 20 years in the Mexican legal system, and that this resulted in their economic marginalization and political subordination under the law. Consequently, a series of rights were created for indigenous peoples, including the right to self-determination, and the right to autonomy.

The process carried out in Cherán created political conditions that were unique in Mexico. Cherán's political structure works within the context of state law, but incorporates a new dimension that is based on an entirely different political framework. Political parties no longer have a place in Cherán; instead, the elections are carried out openly in the community according to practices that are entirely their own. Also, instead of selecting a municipal president under the state political structure, the people of Cherán choose twelve Keris ${ }^{6}$ to represent them in the Major Council of Communal Government (MCCG). This council represents the community, but it is not considered the highest authority. As part of a political landscape which is based on participation and deliberation, the highest authority in Cherán is the General Assembly, although since the revolt it has been structured in a process of decision making in four

\footnotetext{
${ }^{3}$ While it is only possible to give a short account of the process in Cherán in this article, the case and its legal strategy is further developed in the work of Aragón $(2013,2015)$.

4 The name given to the people that cut trees illegally, and often extensively.

${ }^{5}$ The faculty of attraction is a tool provided to Mexican higher courts by which they can decide to deal with, and rule on, cases that are considered particularly relevant, but would not normally fall within their jurisdiction.

${ }^{6}$ Name given to their representatives.
} 
Neighbourhood ${ }^{7}$ Assemblies in which the whole town can participate, and where the main decisions are made. The decisions of these assemblies are then carried out by the Keris.

This is the political context that makes possible the work developed in Kejtsitani. As we mentioned earlier, Kejtsitani is a project to document the oral history of the community ${ }^{8}$ that was born after a series of workshops organised, first by the UG and the National School of Superior Studies (ENES) of the Autonomous University of Mexico (UNAM), and later joined by a researcher at the National Institute of Anthropology and History (INAH), in Cherán. These workshops initiated a great interest for some community members regarding their own history and how it could be preserved through documentation. Kejtsitani means "living memory"; it is a word that refers to the processes of communication and to a history that is constructed every day as it is built into the collective memory of the community. The mission is clear in the name, because it expresses the commitment of those involved to keep the memory alive.

Kejtsitani has brought together a rather large group of people from diverse backgrounds and interests. Some are local scholars, people from the community with higher education that bring not only academic expertise, but also a deep reflection of their own community. Others are a younger generation, still in school but with their own technological expertise, and a profound commitment to the community project. In fact, Kejtsitani's work has often been framed in the context of the Youth Council (Torres 2017), which is part of Cherán's government structure. From outside of the community the group is also diverse; it includes Master's and Doctoral students who conduct field work in Cherán and are also involved with Kejtsitani, as well as established researchers who often come with their students, usually in the course of their first degrees. It is important to note that the coming together of this diverse group of people is also connected with Cherán's struggle for self-determination.

\section{Transforming a challenge into an opportunity: why and how to establish a dialogue about intellectual property and research ethics in Kejtsitani}

As the project of Kejtsitani grew, so too did its scope of action. Two researchers from the UG in the project sought to involve their students and their Laboratory of Oral History to bring more resources to Kejtsitani. They therefore suggested signing an agreement between Kejtsitani and the UG. The members of the Fogata felt they needed help from legal experts, which in turn brought the collaboration of the Collective Emancipations as legal advisors of the community. Lucero Ibarra Rojas is a member of the Collective

\footnotetext{
${ }^{7}$ Cherán's structure is divided in four different neighbourhoods that are currently quite central to the organisation of the community. When elections are carried out, each neighbourhood acts as a sort of electoral district where Keris are elected. In regular conversations it is also common to identify people by the neighbourhood they belong to.

8 The work in Kejtsitani joins in a tradition of oral history projects in Latin America that aim to the construction of knowledge with indigenous communities (INAREMAC 1985, Rivera 2012, Criales and Condoreno 2016). The aim of this article is not to provide a full scope of Kejtsitani as an oral history project, but rather to explore its contributions on intellectual property and research ethics, therefore we will not engage in further comparison over this experiences regarding their agenda in oral history. However, many of these experiences do bring insight over the methodological and scholarly implications of this kind of knowledge production.
} 
Emancipations with expertise in the intellectual property field and a researcher at the Centre for Research and Teaching in Economics (CIDE), which made her involvement relevant for the matters discussed in the agreement; she brought Ezequiel Escobedo Osorio to the collaboration, who was at the time her research assistant and a law student at the CIDE.

Although we started the conversation with a standard state-law oriented draft agreement provided by the UG, our aim was to create an almost entirely new document that duly expressed our actual agreements in working with the community. The process of creating this agreement was both an opportunity and a challenge that brought to Kejtsitani a new sense of self-identification, and influenced its aims and basis of interaction. Though they debated, and continue to debate, the pertinence of the agreement, Kejtsitani participants also saw the opportunity it represented, not only to enhance the project's resources, but also to provide a basis for future decision-making. The agreement also meant that members of the Kejtsitani now faced the challenge of transforming the organic processes they had carried out into a formal legal document.

This article is a secondary result that both explores the process developed for the agreement with the UG and entailed a longer and deeper conversation methodology that can be considered within the universe of collaborative research. By now, there is a relevant tradition of collaborative methodologies in Latin America, that concern with issues like how to build knowledge with social actors and the role of academics, including activists' concerns (e.g. Hale 2006, 2008, Speed 2006, Leyva and Speed 2008, Hale and Stephen 2013, Hernández 2016). Other experiences of building knowledge with indigenous communities include the oral history workshops experiences mentioned above. As many of those experiences, this article is not a result of a research project designed as such nor did it emerge from an intention to replicate those experiences or methodologies. Rather, it was built from a process of collective construction of knowledge and reflection over its meaning, implication, and its ethical and epistemological framework. The UG was interested in an agreement with Kejtsitani, and we found an opportunity to do more than simply sign a document; sort of stumbling in the process with a conversation that turned into this article. Thus, there were two overlapping stages to this process.

The first stage was creating the document that can be seen as a decolonization of intellectual property. In that document we set up to build a regulatory framework that expressed the ethics, epistemological convictions and social commitments of the people in Kejtsitani. It is often said that the community has its own times; these are the times of deliberation that require sitting down and considering many voices. We have become familiar with these times as we have been developing this work. The first meeting ${ }^{9}$ was carried out in the city of Morelia - capital of the state of Michoacán. The problems of the agreement were quickly transformed into opportunities as we discussed a new regulation and even the possibility of developing a community-based creative commons licence. From there we met every two weeks in Cherán, for four-hour meetings, in which

\footnotetext{
9 The meeting, as a communicative event in which many participants talk and develop conventions to organise who talks and when, can be carried out in different ways. It is itself a form of interaction that is relevant for social studies on indigenous peoples' participatory processes, and relations with state agents (Hagene 2015).
} 
the implications of the agreement were discussed and different drafts were exhaustively analysed.

Since the collaboration was not motivated by this academic project, but rather, by the needs of Kejtsitani in regard to the agreement with the UG, this made possible new commitments in academic work to the political project of Cherán. The members of Kejtsitani devoted time and intellect to this project as a testament to their commitment to the community. This does not mean, however, that the process was entirely smooth and simple. As we have discussed, in Kejtsitani, involvement in the community is a daily process of contradictions; turning something that is apparently negative, like disagreement, into something positive, like a proposal to move forwards. Although we subscribed to collaborative and activist research, since our involvement did not begin as a research project, we were not bound to a previously designed methodology. The meetings were not workshops in which the legal experts "explained" the law, nor focus groups in which we studied the answers of others. Rather, they were meetings; spaces in which different voices were heard, concerns were raised, and in which we sought to consider/develop agreements. Our experience could be characterised as participant observation, in the sense that we documented a process in which we participated. It was not intended as such, as the participants were not expressly thinking to develop a research, rather we sought to maintain a larger political commitment to Cherán's process that has not necessarily been present in other research experiences. This is, perhaps, why this project is inextricably connected to Cherán's political process. Because the document we were drafting only makes sense in this context and through the political commitment embedded in the project of Kejtsitani.

Though the aims of objective interaction with a research object in fact discourage this kind of commitment, our work was not just to listen and interpret, but rather to collaboratively construct an agreement from a position that is explicit about our choices, aims and commitments. Hence, rather than hide behind the veil of objectivity, we purposively sought to make choices, aims and commitments that acknowledged our role as researchers in general, and also maintained a political commitment to Cherán. Even if those of us who are scholars were not exactly engaging in research at the time, this form of engaging in social processes was central to our work. In this collaborative context, our legal expertise was not meant to dominate the discussion, because the aim of Kejtsitani was not to submit to state law, but to reaffirm Cherán's right to autonomy, and the commitment of those involved to behave in a way that was coherent with the community's expectations. How were we to guide our research? How should we conceive an oral history project that is committed to, and reflective of, the goals of the community? These questions were essential to our efforts.

Sadly, there was already a bad academic precedent that also informed this endeavor. It should be no surprise that Cherán's political process awakened great interest in the academic community. Indeed, hundreds of theses have already been written in different institutions and many more are being written (e.g. Velázquez 2013, Bárcena 2013, Martínez Navarrete 2017, Santillán 2018). For the past couple of years, researchers have even been invited to share their research on this topic in a colloquium with a packed two-day program (Lemus and Keyser 2017). One thesis, however, stands out for its complex relation with the community. $\mathrm{A} \mathrm{PhD}$ thesis, written from a factionalist 
perspective, is highly critical of Cherán's project. It should be noted, however, that the people in Cherán have little information on the work. ${ }^{10}$ The word in the community is that a work is careless with the identity of the people it purports to represent. While the content of this thesis was not widely debated in Kejtsitani's meetings, it did inform the perspective of researchers involved in Kejtsitani, who sought to carry out work that respected the right of the community to know what is written about them, and to have a chance to contest it. For the people in Kejtsitani, the community cannot be a simple object of research; a source to be exploited for the interest of researchers.

In line with this commitment and as a result of the second stage of our process, the actual methodology - as in a series of steps that turn experience into research, and research into a scholarly product - developments from an extended conversation. ${ }^{11}$ This article is the result of a process of deliberation that has involved people from Kejtsitani, from the wider community of Cherán, and from the scholarly community. The experience of Kejtsitani only became a scholarly concern through the opportunity to participate in the workshop The Policy of Cultural Rights: Socio-legal Perspectives on Cultural Diversity, which was carried out in the Oñati International Institute for the Sociology of Law (IISL) in Basque Country, on July 20-21, 2017. This workshop included participants from countries such as Spain, Canada, USA, Mexico, Colombia, Australia and China; who were interested in the interactions between state and culture, through regulation and policy, in contexts of cultural diversity. The workshop brought an opportunity to systematize and expand our experience, though it also required us to bring out our interactions in the English language. We developed a first draft to structure the aims and discussions in which we had been involved during the deliberations of the UG agreement to be presented in the workshop, and then the workshop participants brought important reflections and questions that enriched our work. Afterwards, we brought the discussion back to Kejtsitani sharing the draft in Spanish and recovering the contributions of the workshop participants. The Fogata decided to hold a special session to further discuss the content of the document. On September 15 ${ }^{\text {th }}, 2017$, the Fogata Kejtsitani met in Cherán to discuss the content of that first draft. This meeting included two special groups of guests which again extended the scope of the conversation: local scholars that specialize in Purhépecha culture and language; as well as other members of Kejtsitani with backgrounds in fields like history, sociology and philosophy. We circulated the draft beforehand, and its content and proposed principles were further developed in a collective manner. ${ }^{12}$ Thus, by including Kejtsitani as an author in this article, we acknowledge the collective process of deliberation that this article represents and seek to represent an ethics of ownership that recognizes the essential role of Kejtsitani in its production.

\footnotetext{
${ }^{10}$ We do not include the reference to this work because the document is in fact not known to the Fogata Kejtsitani. Its role in the discussions in the community are relevant also because of its detachment from the community and from the sense of distrust of researchers that it has brought to many people in Cherán.

${ }^{11}$ A similar methodological approach is documented in the case of the cultural project Eltzia, developed in the town of Oñati in Basque Country, and which is part of this issue of Oñati Socio-Legal Series (Ibarra et al. 2019 , in this issue).

12 The book Juchari eratsikua, Cherán keri: retrospectiva histórica, territorio e identidad étnica, is also reported to have an origin in a workshop process of continuous interaction between the participants (Lemus and Keyser 2017).
} 
In this sense, the building of knowledge through a conversation between a group with different backgrounds can, and indeed was used, for two different instances: the production of a legal document and of a research article. Even though the products differ, the inspiration, the political stance and the commitment to building from a conversation that is nurtured by agreement but also by different stances remained. Both products result of an interaction that aims to build on knowledge over the legal form from perspectives that are not common to lawyers and constitute an important contribution to socio-legal studies. The legal document bears no authorship but expresses the interest of Kejtsitani to question several issues of intellectual property. This article acknowledges an authorship, but aims to express the ethical and epistemological commitments that we have expressed in the agreement, and which will be explored in this article.

But the academic discussion is also not a mere expression of the results from the construction of the agreement document with the UG. The discussion meeting expanded significantly the scope of the article and brought new challenges to our work, including the issue of language and the complications of translation. Different members of Kejtsitani presented the proposal to use Purhépecha terminology for the principles we present in this article, but as most of the work we conduct in Kejtsitani is in Spanish, there was often no direct translation. Indeed, as was highlighted in the discussion meeting, many of the terms that we use in Spanish do not have a direct translation from Purhépecha and, vice versa, the Purhépecha entails its own worldview in a "customs and habits-culture" structure that speaks of the territory and the concepts that memory carries through time (Silva 2017). Thus, while the agreement was developed in the Kejtsitani's context, and was fundamentally shaped by people from Cherán, and by their culture, it was also developed in Spanish, as the shared language of all participants. But rather than generating a barrier to understanding each other, this has instigated perhaps the most interesting discussions of how we frame issues, what language we use, and the meaning we give to words.

The challenge of language is enhanced in the context of a research article. Academic language is specialized by nature. Even though many would agree that it needs to be more accessible in order to serve the societies for which we write, scholars spend years developing a form of expression that gives words specialized meanings. This is part of the distinction academia builds for itself but becomes an issue that needs to be addressed. ${ }^{13}$ The many scholars that have passed through Cherán have left a testament of this in the memory of the people. Scholars brought to Cherán the "concepto doble ancho" (double wide concept). The analogy is taken from knitting techniques characterized by their complication and it is the way the father of one of the members of the Fogata refers to the words scholars tend to use. The double wide concepts are no longer foreign to the community, and rather, the community has incorporated some of these concepts into their speech and into an understanding of their processes. This has happened in part as a result of academic participation in assembly meetings, which are important political deliberation spaces in the community. In the meetings, people that

13 The San code of ethics, for example, includes the following provisions: "The language must be clear, not academic. Complex issues must be carefully and correctly described, not simply assuming the San cannot understand. There must be a totally honest sharing of information. Open exchange should not patronise the San" (South African San Institute 2017, p. 2). 
may only have a few years of instruction interact with others who are in the final years of their education. As scholars make an effort to communicate in this setting, they also contribute to the narrative of the community.

Additionally, the workshop brought other voices to the conversation, but also the challenge of yet another language to interact with. As scholars, we are accustomed to translating our ideas, and contact with English literature shapes certain aspects of our expression - though we are profoundly thankful to the editor of this article -. The specialization of academia makes this issue easier as words acquired specialized meanings. But translating the discussions of the Fogata is more challenging. The discussions often dealt with the correct use of words and their specific, and frequently contested, meaning, particularly when compared with Purhépecha. Though we do not believe this creates an immovable barrier to communication, we must express that it is not possible to do justice to the richness of the reflection over language without turning this article into one of linguistics. We have, however, limited the use of unnecessary double wide concepts, and have tried to clarify when expressions are odd in English, but particularly meaningful in Spanish; including some of the discussions in Purhépecha as well. Additionally, our commitment is that this article becomes part of the Kejtsitani archive and is published in Spanish and in Purhépecha as well.

We must highlight that, even though our collective concern is to work within ideas and concepts from the community and not from abstract and foreign theories, the result is much more complicated as a result of academic participation in this project. Scholars tend to be outspoken in Kejtsitani meetings and we are part of Kejtsitani. Further, the scholars from Cherán tend to have even more authority, even if we aim to interact beyond those distinctions. As a result of scholarly participation in the meetings and the general familiarity of the people from Cherán with double wide concepts, knowledge of the community is not created from a field that is foreign or entirely other to that of social sciences or mainstream law, even though it is often developed in opposition to them. While scholars tend to be particularly concerned with finding "the right" phrasing or concept, however, other participants consistently challenge words because of the connotation they have outside of the ivory towers of academia. In between these positions, we try to build on something that sounds right to most of us. Of course, this also had to be negotiated with a process of peer-review which brought the need to incorporate far more literature than we had previously considered or shared in our conversations; therefore, we often clarify its place as scholarly reference, though not as inspiration or guideline. We would satisfy a folkloric fetish, but would be less than honest, if we did not acknowledge that this discussion is not a translation of indigenous worldview, but is a place of encounter between different worldviews, backgrounds and academic fields, ages and life experiences. It is, if anything, an intercultural project. ${ }^{14}$

\section{Building on Cherán's autonomy and institutions: how Kejtsitani contributes to the continuous process of law creation in Cherán}

Orlando Aragón (2017) states that Cherán's process since it gained the right of selfdetermination has been one of a living constitution; that is, a continuous process of law

\footnotetext{
14 Taking on a description of "interculturality" as a recognition of difference that aims to project a shared agenda forwards (Walsh 2009).
} 
creation, resulting from the negotiation between Cherán's people to redefine the social pact of governing. In this process, the work we have developed in Kejtsitani is one of imagining the possibilities and developing new understandings of law and institutions. Indeed, in being consistent with Cherán's right to autonomy, the first step was to deal with Kejtsitani's identity. When they articulated Kejtsitani's project, they organized it as a collective, that is, as a group of people working together towards an aim. However, used in the legal sphere, as the UG agreement required, this word had a different meaning. Under the law, it was a form of the state, which imbued it with specific possibilities. A scholar from Cherán in the field of education was the first to bring forward this issue in the first meeting in Morelia. He suggested that perhaps it was necessary to reconceptualize Kejtsitani as a communal form and suggested thinking of it as a Fogata.

The notion of the Fogata was constructed and became relevant in the context of Cherán's mobilization (Aragón 2013, Velázquez 2013, Calveiro 2014, Jerónimo 2017). When the community of Cherán rose up against organized crime and expulsed both the talamontes and the local government, they also took the responsibility of local security into their hands. They installed bonfires (fogatas) in many parts of the town as vigilance posts to work through the night and identify any threats to the community. The people in each block would handle their bonfire, establishing turns to sit in and to bring food and wood. Hence, the bonfires became a smaller unit of deliberation, where news and initiatives where brought forward, even before the Neighborhood Assemblies where established. Many Fogatas were kept after Cherán's new government was formed and became part of its political structure, so the people of Kejtsitani felt that the Fogata was a form representative of Cherán's struggle. That is, it came from the community's political process; it expressed their identity as a deliberative space working for the benefit of the community; and it was open to, and worked for, all. Taking Cherán's autonomy seriously began by understanding that the collective Kejtsitani was not legally recognized because it had never been registered, but the Fogata Kejtsitani had legal status if it was recognized by the authorities of Cherán. As such, Kejtsitani's legality and legitimacy comes from Cherán's autonomy process.

A second consideration in signing the agreement with the UG was the place of the Fogata Kejtsitani within the community, as well as its relationship with Cherán's authorities. It is important to note that the openness and willingness of the UG researchers during negotiations with scholars in the Fogata Kejtsitani also made many of these processes possible. This negotiation included a visit by members of the Collective Emancipations, which was accompanying the work of the Fogata, to the UG, to talk about Cherán's process of achieving autonomy, and the legal and political relevance of the agreement. The UG was willing and even enthusiastic about undertaking a new kind of agreement that was marked by a commitment to an indigenous community. Therefore, no objection was made to the proposal of putting the agreement under Cherán's jurisdiction and to having the Fogata signing as such, as long as it was recognized by the MCCG. The requirement to be recognized by the MCCG was the outcome of a lengthy deliberative process that was decided upon for two reasons. First, it was believed that the agreement with the UG would be much stronger if it included both the Fogata and the MCCG as representatives of Cherán. Second, if the MCCG knew of, and supported, the work being developed in Kejtsitani, the principles and commitments developed during this process 
of deliberation might become a model for future research carried out in the community, though express a concern related to research and development projects that far exceed the context of Cherán (Matsui 2015).

Since the MCCG is not Cherán's highest authority, however, it was necessary to gain the Neighbourhood Assemblies' support. In fact, Kejtsitani's project had already been presented in the four Neighbourhood Assemblies, not only to inform the community, but also to invite those who might be interested in Kejtsitani's agenda to participate. Kejtsitani is, after all, considered to be an endeavour open to the entire community and to researchers from different fields that want to participate in documenting and adding to the living memory of the community. As a result, many of Kejtsitani's activities are intended to engage as much as possible with the community. For most of its activities, the Fogata uses divulgation strategies for inside and outside the community. ${ }^{15}$ For the agreement to be signed by the MCCG, however, a new visit to the Assemblies was necessary. For this, Kejtsitani prepared materials to inform the community about the agreement, including: a radio spot to introduce the main points of the agreement and to inform the community that it was going to be presented in the assemblies; an annotated version of the agreement to be posted on line so anyone could access it, and also understand the relevance of its main points; a printed pamphlet describing these points; and power points on both the agreement and on Kejtsitani's work and trajectory.

Assembly discussions on this matter are ongoing due to new challenges that have arisen at this stage of the process. The Assembly of the Second Neighbourhood was visited on November 15, 2016, by two members of Kejtsitani from Cherán, a Master student from the Centre for Research and Superior Studies in Social Anthropology (CIESAS) and Lucero Ibarra Rojas. Although the parties had agreed that the local members would present the initiative, Lucero's presence made it possible to request her assistance in the presentation, which also happened in the Assembly of the Third Neighbourhood on November 17, 2016. The people of the Second Neighbourhood seemed mostly interested in the possibility of knowing more about the different research projects carried out in Cherán. However, the agreement raised additional questions regarding the place of Kejtsitani within the community, mainly in relation to instances like the colloquium organised each year and the Education Commission. The following day was the meeting with the Fourth Neighbourhood, but the agenda that day was too busy to include the matter of the agreement. In the meeting with the Third Neighbourhood, interest was again focused on the importance of having more information about research projects in the community, but there was also an emphasis on maintaining open communication between the universities and the community. The meeting with the First Neighbourhood was postponed due to the Assembly's busy schedule. The meetings with the Second and Third Neighbourhoods demonstrated general concern in the community regarding the many researchers that visit it. In fact, in both cases the dystopic thesis was mentioned by

\footnotetext{
${ }^{15}$ Kejtsitani has a blog to share their work with the world, and they broadcast all their activities on the radio; recently they also discussed a project to create audio-visual content and a weekly radio program. The radio is very important in the community, as it is the main medium of mass communication. In fact, the uprising of Cherán also included the creation of the Radio Fogata, handled by the community as the main news source for the general public. The issues that they deal with include women's participation, the relation of migrants to the community and even their relation to? The legal processes of the community, including the agreement with the UG.
} 
the participants. Before new presentations are scheduled with the Assemblies, Kejtsitani has decided to review the plans for the agreement.

\section{Research ethics and intellectual property from Cherán}

The times and processes of the community are certainly not those of academia. Nevertheless, the deliberative process of Kejtsitani, even at this stage, provides a way to think about research ethics and intellectual property that is articulated from principles shaped by the actions and commitments of the community, and by the researchers that have come to work within it. The principles that we articulate here have been outlined in a document to be signed by Kejtsitani and the UG that was constructed through the deliberative process of Kejtsitani, but that was also envisioned as a model that could be followed by researchers in Cherán in general. Within Kejtsitani there is an often made joke about how the community must now teach researchers how to do their research, but it was no joking matter for those involved, many of us researchers as well. Indeed, the experience was one in which we considered ourselves both subjects and researchers. We tried to find a balance between the two roles, and to form a pact between all those involved to overcome extractivist practices.

Although new principles may continue to develop in Kejtsitani's work, these are the basic principles that can be drawn from the agreement between Kejtsitani and the UG:

\subsection{The principle of communitarianism}

This principle represents the main commitment of the people that work in Kejtsitani, hence, the main objective of the agreement is defined in the following terms: "to establish the basis for collaboration between the parties, to work in benefit of the community of Cherán". The principle of communitarianism in this agreement is based upon two main complementary aspects: reciprocity and challenging individuality. The project of Kejtsitani is itself a collaboration between people within the community and people from outside it, with the documentation of the community's living memory meant to be a project that is accessible to all. Many of the activities of Kejtsitani are oriented around divulgation in the belief that the memory documented belongs to Cherán's entire community. The agreement establishes a requirement that the work of researchers is known in academic forums and in the community. Researchers commit to presenting their work to the Fogata and also to the community in cases in which a wider discussion is deemed pertinent by Kejtsitani.

Though one could explore different conceptual understandings of the notion of community/communitarianism/communality, we are interested in how the Fogata understands their role in relation to the community. Indeed, this article originally termed this principle as "communality", a concept that is used by some people in Kejtsitani who have come into contact with the intellectual productions of Oaxacan thinkers (Maldonado 2015, Martínez Luna 2015, Esteva 2015). However, we struggled in the discussion meeting to find a similar discussion and even a translation to Purhépecha. Instead, we discovered different ways of understanding our role in the community as scholars and as participants in an oral history project and how these roles are expressed by our work in Kejtsitani. 
As was explored in the discussion meeting, one can be in the community or "make community" or "feel as a community". People that live in Cherán can be in the community without being part of the political project, but participate in different ways. Some groups, for example, are still in political parties and do not participate in Cherán's political project, others adhere to specific religions that do not subscribe to some holidays - and holidays are widely recognised as essential to the community life -; but they contribute in other ways and remain connected to others due to family or friendship ties. However, for the people in Kejtsitani it is more important to "make community" (hacer comunidad), upon the understanding that being in Cherán is not enough if you do not contribute. Making community means leaving aside your own concerns to contribute to the collective, to work on behalf of togetherness. Far from being a static notion anchored in the ideal of tradition, the community is a dynamic experience of contribution for the benefit of the group. The community is thus something we achieve together that rests in the notion of "living in support"; 16 built in every day practices and actions, in the active sharing and supporting one another. In the context of Kejtsitani, being a community is embodied in spending time and energy committed to documenting the communal living memory. This, in turn, advances an ethical notion of belonging expressed as "feeling as a community". This expresses the emotional attachment that is best demonstrated by the act of defending Cherán and its people. Indeed, the sharing experience becomes a process of connection among those involved and creates conviction over the future and what is being constructed. The scholars that join Kejtsitani from outside Cherán develop a personal connection that often compels them/us to defend the process of which we are part of. Similarly, Cherán backs up its supporters like the Collective Emancipations when others try to undermine its commitment to the community.

The explanation of the community as built on everyday sharing could be understood as an idealised notion of the interaction of people in Cherán, but this would be a misconception. The discussion in the meeting regarding this article widely emphasised the role of conflict in the everyday of being a community, thereby demonstrating that sharing means accepting communal responsibility for the bad as well as the good. Indeed, being a community means dealing with contradictions, and means learning from conflict and disagreement. The aim to build a community and feel as a community, undoubtedly, and consistently with previous observations on the methodological approach of this article, challenges the distance between researcher and subjects upheld by more positivistic approaches. It expresses more clearly, however, the aims of activist and collaborative researchers, and creates a distinct set of ethics and attribution in the work.

It is important to note that this construction of making community and/or feeling as community is also profoundly linked to Cherán's political process. People in Cherán would, of course, interact with each other before they faced the issues that led to their raising; but the political resistance brought them closer together in the need to construct structures to defend themselves and continue forward. This does not mean that every single person in Cherán is politically active and a model of participation and engagement with a political project. It also does not mean that there are no leaderships, charismatic

\footnotetext{
${ }^{16}$ The expression used in the discussion meeting was "vivir en apoyo", which is a notion that includes living to support others and a life in which you feel the support of others.
} 
or politic, that become central to the continuation of their political project. Rather, it is a testament of a structure that has been constructed to provide spaces in which citizens can express themselves, demand accountability and create new projects that serve the community. The challenge remains for Cherán to keep these structures alive with each government change and despite the demands of everyday life.

The commitment to reciprocity and challenging individuality, outlined in the agreement with the UG, is also reflected in how the authorship of the academic product is expressed, since authors are required to acknowledge their work as part of the community's heritage, and the collaboration with Kejtsitani in its development. This not only calls into question the individualistic nature of intellectual property, but is also a commitment that challenges traditional academic practices of authorship and appropriation. When discussing this point, the main concern was indeed the exclusionary way in which the notion of property is conceived (Picciotto and Campbell 2003), and how it makes community sharing impossible. Scholars and practicants of intellectual property have long been concerned with questions of collective and even massive authorship (Cooper 2015) that have been renewed by digital technologies.

However, the contribution of the author/scholar was also a point of disagreement in the discussion meeting. As one of the PhD students argued, scholars do not just transcribe what they observe, they bring knowledge, systematization and analysis that owes much to their own academic background and their effort to effectively build knowledge. As Kejtsitani works in an oral history project, another scholar contended that the knowledge, as saberes, of the community is eminently oral, while scholarship knowledge, as conocimiento, depends on a written structure. In his argument, orality is the main difference between these two words. However, the term "saberes" has also been used to refer to indigenous knowledge to express its colonial separation from scientific knowledge (conocimiento). We were again faced with a distinction that we could not entirely resolve. Especially since, with Kejtsitani, scholarly efforts are only possible in the process of sharing, often in oral settings; and were dependent upon the willingness of others to let us witness, interview and, often in Cherán, effectively part take in the community's activities. While the independence of any written idea to belong to a single person was something we found nearly impossible to affirm, in general, we believe that there should be an acknowledgement of the work a person puts into her intellectual production.

Our answer was expressed in an ethics of shared belonging and recognition. Can something be mine and also be ours? We recovered and recognised the value of authorship as an acknowledgement of the work a person puts into something, but agreed that this could not preclude recognizing the contribution of others, nor could it prevent others from accessing the work. In her own work, Silvia Rivera Cusicanqui (2012) expresses a context in which collective authorship is rejected in acknowledgement of the work and interests that dominate her final product, which is in fact a co-authorship (Rivera and Lehm 1988). Nevertheless, we parted from a different set of concerns that are expressed through authorship. As a strategy of acknowledgement, rather than of property, authorship can be a way to assert different belongings that are not exclusive, and can express the value we put into the work through the creation of something, 
without automatically meaning that a commercial monopoly is necessary. ${ }^{17}$ This article can be ours because we have put our pens to it, we have devoted time, energy and reflection to produce it, and many years of education and learning into developing the skills to create it. It is Kejtsitani's, at the same time, because it is made from the collective reflections of its participants, and from their collective will to build on something we can share. It is also Cherán's, as it is about the political project of Cherán and the notions that form during everyday interaction, and it is the product of their willingness to share, educate and learn from the people that go there to do research.

\subsection{Principle of no commodification}

The second principle represents the commitment to avoid interactions based on economic benefit. During the discussion of the agreement, people in Kejtsitani were insistent that the agreement explicitly that the work done in this project would be nonprofit. This principle was taken even further in that even the phrasing related to private information was changed to "information that will remain internal to the community". This was because the people in Kejtsitani related the idea of something being private to a potential economic benefit, that is, "for something to be sold, it has to be private". From a legal perspective, however, this is not necessarily the case, and in relation to private information it is precisely the contrary, as being private in this case represents an argument against something being sold or distributed. The notion expressed in Kejtsitani, on the other hand, was more informed by the privatization of formerly public companies, a practice that can be attributed to the neoliberal agenda of the Mexican government. Privatization has been central to public discussion since the 1980's, and this discussion has become more prevalent over the past years with the privatization of the oil industry. This was a lesson on the way language is naturalized and disputed within social practice.

The agreement, then, establishes that the people involved will seek open access to their published work, to thereby avoid limiting access for the purpose of economic gain. In the first academic discussion of this article, the distribution of economic benefits under intellectual property law was a major concern. Indeed, one of the underlying principles that supports the need for intellectual property is the notion that people will not create if they cannot exclude others from benefiting from their creation (Drahos 1996). This notion has some incongruity in the academic field, as the economic benefit rarely falls on the author. Academics are not alone, however, in pointing out that the value of their work is precisely in its dissemination, since the value of creative endeavors increases as they become increasingly known. Perhaps because of the widespread agreement on this issue, it was seldom discussed, but we tried to engage Kejtsitani's participants in further reflection on this issue during the discussion meeting. Despite our insistence that the activities of Kejtsitani could lead to some economic benefits that would need to be addressed, the members of the Fogata rejected the idea of including any reference to patrimonial rights contemplated in traditional intellectual property. Their reasoning was that part of the ethics of being a community is in giving without expecting money in return.

\footnotetext{
${ }_{17}$ Similar arguments can be found in feminist critiques to intellectual property (see Craig et al. 2011).
} 
It was clear that the participants did not think that much economic gain could in fact be obtained from Kejtsitani's activities, remarking that the project is more likely to require an economic contribution from its participants The people from Cherán do wonder what scholars gain from travelling all the way to Cherán and working in Kejtsitani. The activities in Kejtsitani enrich the intellectual life of the persons involved, which also benefits our work environments, but the greatest contribution is what we learn and what we create together, in making community. It is not an altruistic endeavor; rather it is based on an acknowledgement that intellectual activities are valuable because intellectual enrichment has a positive impact on other aspects of our lives. Upon our pressing the subject, the Fogata decided that a good strategy to handle any money that came its way would be, once the basic needs of the Fogata were covered, to go to the Neighborhood Assemblies and ask for a deliberation on the best destination for the resources. The basic needs of the Fogata were mostly represented as food for the meetings. The Fogata does participate in scholarly activities outside of Cherán, but travel expenses are often covered by the academic institutions or by the organizers of the activities, though occasionally the members of the Fogata contribute money to participate in scholarly activities. Regardless, it is important for the Fogata to be clear on how much money is being handled and to what end. In fact, this is a main concern in Cherán as the people are very aware of the transparency responsibilities of their authorities and issues pertaining to money are treated with the utmost sternness. This is both a reaction to widespread issues of corruption in the country, and also to processes in which cultural productions like the Pirekua, a traditional song typical of the region, have been subjected to UNESCO recognition to the benefit of only a few stakeholders (Flores 2016).

During this discussion, another common concern was that other contested gains could be made from Kejtsitani, including prestige or power. Knowledge can be a source of power, and the community's intellectuals have a special place and voice in assemblies. But one of the concerns of the scholars in Kejtsitani was that the knowledge fostered in this experience did not reinforce inequalities. In Kejtsitani meetings this is expressed by the constant motivation to hear less outspoken voices, and by the constant vigilance of participants to not impose points of view. In the community, and in Kejtsitani's aim to keep alive the memory of the people of Cherán, this concern is reinforced by making Kejtsitani's activities widely known, and by ensuring that they are presented in formats that are accessible to everyone. This, in turn, reinforces the notion of collective ownership: it is not the individual scholar that is known in Cherán for the work of Kejtsitani, but rather the group itself.

\subsection{The principle of openness}

The principle of openness is closely linked with the previous two principles of communitarianism and no commodification, and responds to the main concern of the community, as expressed in the Neighbourhood Assemblies when the agreement was presented. It is clearly expressed in the intention to carry out activities that are accessible to the entire community and to publish in open formats, but it goes beyond this in the proposal to create a community open access license. This is perhaps one of the most ambiguous aims for Kejtsitani. On the one hand, it implies using a model that makes direct reference to intellectual property, which would be regulated under state law. On 
the other hand, it can also connect Kejtsitani with other collectives that seek to use intellectual property globally, while responding to its current insufficiencies in representing interests like those of Kejtsitani, and can help to create a world in which legal tools can be used to protect the act of sharing and collaborating. ${ }^{18}$

As was mentioned earlier, the agreement includes the possibility for some information to be declared internal to the community if it relates to religious practices, internal political structures, or if it poses a risk to someone's safety. However, this is an exception meant only for the protection of the community. Kejtsitani's commitment to openness is clear in the project itself, in that everything Kejtsitani documents is meant to contribute to an oral history archive that is available to everyone in the community, and to researchers interested in Cherán. In return, researchers are to share their work with Kejtsitani and with the community.

When the agreement was discussed, at least one researcher expressed the concern that the commitment of disclosure of the research to the community created the possibility for Kejtsitani to oppose the publication of works that were critical of the project of Cherán; though it was clearly stated by all members of Kejtsitani that this was not their aim. As a result, the agreement was changed to state that the presentations would be only for the purpose of sharing the work. This issue relates to the way in which conflict is understood in Kejtsitani as productive in community processes. As was explored in the discussion meeting, to live together (convivir) ${ }^{19}$ is a process of sharing and learning from differences, and the people that meet in Kejtsitani believe that there is much to learn from critiques of the community and its political project. Indeed, in a number of instances, participation in Kejtsitani necessitated that its contributors not shy away from disagreement, but rather bring forward all of their concerns. From there, they sought to work out new and better solutions, though this process included making compromises and allowing for the possibility that some ideas or proposals might be better than others.

Especially in the context of Kejtsitani, openness is essential to the possibility of creating and developing knowledge. One must remember that Kejtsitani is in essence an oral history project. Far from being something we own or possess, in the discussions in Kejtsitani, knowledge is something that we live. Memory is the way in which one knows, but is also the way in which one belongs to the community. The act of communicating knowledge, and even the documentation of oral history, are forms in which people connect and make community. If one believes that the transmission and discussion of that knowledge is an essential part of making a community, the idea that this knowledge could be owned by a single person in an exclusive manner is impossible. Furthermore, the scholars in Kejtsitani acknowledge the debt they have to the community, and acknowledge the right of its people to know what is being written about them.

\subsection{The principle of self-determination}

As we have explained throughout this work, the agreement between the UG and Kejtsitani has been developed with respect for Cherán's self-determination. Not only

\footnotetext{
${ }^{18}$ One example of this is the way open access has been identified with a feminist perspective precisely because of its commitment with knowledge sharing (Craig et al. 2011).

${ }^{19}$ Even though the notion of "convivir" is used in Spanish to refer to situations of cohabitation, it is also used to refer to social gatherings.
} 
does it recognise Cherán's authorities and government structure, but the UG's lawyers themselves also suggested a change in the section that deals with the UG as a party to the agreement, to include the statement that the UG respects and recognises Cherán's autonomy and right to self-determination, as well as its customs and habits. In addition, Cherán is given jurisdiction to solve any conflicts that arise from the agreement, and decisions over its implementation are to be decided by Kejtsitani. With this, the agreement consolidates a commitment that is shared by the people in Kejtsitani with the political process of Cherán.

However, reaffirming Cherán's self-determination is relevant as well for the continuous struggle of the community because law remains a place of struggle. Asserting the authority of the community before the state and its law lays the groundwork to continue their defense and resist further attacks to their political project. The first concern we addressed in the discussion meeting was precisely how law is understood and how this understanding shapes how each person and each community relates with state law.

When the notion of law is invoked by Purhépecha language experts, their usage more closely envisions the law as a tool of defence. Jurhimpikua kuajpiri is how they translate law, which is a concept related to having a right to defend oneself, rather than a right to do, or to access, something. This concept was further explained when other ways of understanding law were introduced.

One of the participants, a foreign scholar, introduced the notion of law as rights, ${ }^{20}$ as a subject of rights. Having a right to live, to be respected, to private life, that is: "not something I have to defend, but that by itself is there, something I must have just because I am" - a notion that is common in legal education from a legal positivistic/formalistic perspective. The response to this was simple: "but, regularly, you always have to defend it". Even if it is written in the law; even when it is evident that no defence should be necessary, the life experience of the community is that you must be ready to defend your right. Rights, and law itself, are born from conflict. They do not experience the law as subjects of rights. Indeed, a recent article on the literature from the IISL (Ibarra 2018) shows that work on indigenous peoples in Latin America has often been marked by a concern for the criminalizing actions of the state against these groups during disputes over resources and development agendas. This notion can be linked to Cherán's relationship to state law and the legal process to assert their autonomy in that even though Cherán has been successful under state law, it continues to feel unrepresented by it, and thus always on the defensive. Even if Cherán's right to autonomy and its forms of government are recognized by the state, this has not changed the way the community understands themselves or their way of life. Rather, if anything, it has only reinforced the perspective that their relationship with the state is one of constant conflict and resistance. This is due, in part, to the fact that the recognition has not automatically transformed or their interaction with state agencies, as most bureaucratic procedures are marked by the reluctance of state agents to accept the actual forms of Cherán's government. They are, for example, required to declare a single person a representative of their government, which negates the collegiate form of the MCCG.

\footnotetext{
${ }^{20}$ It is important to note that, in Spanish, "law" and "right" are in fact the same word: "derecho".
} 
Another scholar tried to introduce the notion of law as a solution to conflict. This proposal, presented by a sociologist, would seem natural to a lawyer as well, with law being represented as a structure of norms and institutions to solve conflicts. The literature on legal pluralism portrays the same idea. Laura Nader's (1990) work in the nineties is, for example, representative of a long tradition of scholarly efforts that have been devoted to understanding the ways in which indigenous communities resolve conflicts. In Nader's work, legal pluralism develops as a way to keep the state from interfering in the internal problems of the community. Indeed, communities like Cherán have organised from within, keeping their practices and knowledge out of the state's scope (Jerónimo 2017). However, the current relation between Cherán and state law, and its role in domestic conflicts, is different. Cherán's demand for autonomy is often interpreted by the state as a challenge to which the correct response is to leave the community entirely alone. This has entailed several administrative challenges for the community, and access to the judicial apparatus has become difficult. The notion expressed by the people in Cherán is that their struggle for autonomy has been marked by another challenge: "ah, ¿ustedes tienen un conflicto legal? A ver, pues resuélvanlo". ${ }^{21}$ In this context, Cherán's process of continuous law creation is also a process of defending the right they won, which they use to protect themselves against anyone that aims to undermine their political organization. This shows the complex relation between state law and indigenous law, even in the context of state recognition of indigenous autonomy.

The community is left with the challenge, and the opportunity, of conceiving their place under the law and their sense of legality. They understand their "customs and habits" to be the space in which their legal status is recognized by the state, which they perceive to be a limit of state law. The underlying notion of the discussion is that law is that of the state, meaning that what is recognized in the community by the state is not defined as law, but rather as "customs and habits". In fact, the discussion over what is law and what kind of normativities fall outside this notion is relevant to legal pluralism and to socio-legal debates that aim to establish the possibilities and roles of law between two polarized positions: as dominant colonial and liberal frameworks that undermine indigenous normative structures; or as a space from which to articulate resistance strategies. ${ }^{22}$ In a practical sense, the notion of customs and habits outlined in the Mexican constitution has given communities a basis upon which to demand their place in the Mexican political landscape. The downside, perhaps, is that the link with tradition can become a limitation that precludes any notion of tradition or culture as dynamic and changing. Habits refer to how things have been done, but their autonomy is something that they are building in the present. It is not uncommon for indigenous claims to be undermined on the basis that the claimants must prove that their practices are reminiscent of an untouched pre-colonial past. The notion of indigenous law would not include this burden, as law is established in tradition, as much as it is constantly created and changed. However, the experience of Cherán demonstrates that one can create a new tradition within concepts like "customs" or "habits"; that this new tradition can be connected with previous structures that may have become less prevalent over time; and

\footnotetext{
${ }^{21} \mathrm{Oh}$, so you have a legal problem? We want to see you solve it.

22 These discussions can be found in works like that of Fitzpatrick $(1998,2011)$ and Rivera-Lugo (2014).
} 
that this creation and recovery can be a way to strengthen the sense of local identity and community.

\section{Final thoughts}

The voices of Kejtsitani speak both from the community and from scholarly perspectives, and one of the biggest opportunities of the agreement was to observe how diverse perspectives can work in cooperation, rather than in conflict by working through the conflict as it presents itself. Throughout the deliberation process it was surprising to see researchers waive their prerogatives and rights in favor of the community. Perhaps it should not have been a surprise, given that the political process of Cherán is also of particular interest for politically active scholars. Nevertheless, the collaboration and mutual learning process has potential to transform academic practices through the reflection over the need for academia to be a place of mutual learning instead of knowledge extractivism. As the San people have expressed in their code of ethics: "Andries Steenkamp, the respected San leader who contributed to this Code of Ethics until he passed away in 2016, asked researchers to come through the door, not the window. The door stands for the San processes. When researchers respect the door, the San can have research that is positive for us" (South African San Institute 2017, p. 4).

Indeed, we believe that the work we have done is not only positive and valuable for the community of Cherán, but also to our growth as scholars. Our own work and concerns have been integrated within the agenda of Kejtsitani. Discussions over intellectual property, ownership and what the law is and means for different persons would not necessarily be part of the scope of an oral history project, nor was Kejtsitani particularly interested in any effort of decolonizing intellectual property before the agreement was suggested and the making of this article expanded the conversation. Collaborative methodologies work rarely discusses its implication on the need to rethink authorship structures. ${ }^{23}$ These discussions were the trigger for the redefinition of Kejtsitani's identity as a Fogata. In the same way, research on intellectual property would not necessarily entail concerns over research ethics and methodological practices, but these considerations have been essential to redefining the kinds of commitments that authorship practices can express. Kejtsitani is an interdisciplinary and intercultural space that truly widens the scope and relevance of our concerns.

Under the law, the agreement was an opportunity to construct a regulation based on Cherán's right to self-determination and autonomy, but the process was also a lesson in the way citizenship is practiced in Cherán's political pact. As Juan Jerónimo indicates "autonomy resides in the knowledge [saberes], because the practice of these knowledge is the point of departure for free self-determination, that is, the choice of a way to be" (Jerónimo 2017, p. 136). In the internal work of Kejtsitani, as well as in the way it interacts with the MCCG and the Assemblies, it is clear that political decisions and even legislative work are not a monopoly of the few, but a possibility for many to take part of the choice of the direction of their community. During the discussion meeting, the participants highlighted the way the social movement in 2011 renewed the feeling of community. This is a form of political participation that comes with responsibilities, but

\footnotetext{
${ }^{23}$ As we mentioned, Silvia Rivera Cusicanqui (2012) does engage in a brief discussion over authorship, though with very different results and context than those explored here.
} 
also with a sense of empowerment. Through Cherán's assemblies, all citizens can take part, and indeed must take part, in shaping the legal and political landscape of the community. As we mentioned before, the challenge now is to keep this citizenship involvement alive through changes of government, social exhaustion and the constant obstacles faced by Cherán's autonomic process.

\section{References}

Antons, C., 2009. The international debate about traditional knowledge and approaches in the Asia-Pacific Region. In: C. Antons, ed., Traditional Knowledge, Traditional Cultural Expressions and Intellectual Property in the Asia-Pacific Region: The International Debate about Traditional Knowledge and Approaches in the Asia-Pacific Region. Alphen aan den Rijn: Kluwer Law International, pp. 39-65.

Aragón, O., 2013. El derecho en insurrección. El uso contra-hegemónico del derecho en el movimiento purépecha de Cherán. Revista de Estudos e Pesquisas sobre as Américas, 7(2), pp. 37-69.

Aragón, O., 2015. El Derecho después de la Insurrección. Cherán y el Uso ContraHegemónico del Derecho en la Suprema Corte de Justicia de México. Sortuz: Oñati Journal of Emergent Socio-Legal Studies [online], 7(2), pp. 71-87. Available from: http://opo.iisj.net/index.php/sortuz/article/view/702 [Accessed 12 February 2019].

Aragón, O., 2017. Transformando el constitucionalismo transformador: lecciones desde la experiencia político-jurídica de Cherán, México. Abya Yala, 1(2), pp. 130-149.

Aragón, O., 2018. Otro derecho es posible. Una biografía (intelectual y militante) del Colectivo Emancipaciones. Oñati Socio-Legal Series [online], 8(5), pp. 703-721. Available from: https://doi.org/10.35295/osls.iisl/0000-0000-0000-0963 [Accessed 12 February 2019].

Bárcena, E., 2013. El arte de lo imposible en la era de la democracia liberal. Consideraciones respecto al movimiento de la Comunidad Indígena de San Francisco Cherán como acto político. Morelia: Universidad Michoacana de San Nicolás de Hidalgo.

Calveiro, P., 2014. Repensar y ampliar la democracia. El caso del Municipio Autónomo de Cherán K'eri. Argumentos [online], 272(1), pp. 193-212. Available from: http://www.redalyc.org/articulo.oa?id=59533233009 [Accessed 12 February 2019].

Cooper, E., 2015. Copyright and Mass Social Authorship A Case Study of the Making of the Oxford English Dictionary. Social \& Legal Studies [online], 24(4), pp. 509530. Available from: http://dx.doi.org/10.1177/0964663914565848 [Accessed 12 February 2019].

Craig, C.J., Turcotte, J.F., and Coombe, R.J., 2011. What's feminist about open access? A relational approach to copyright in the academy. Feminist@law [online], 1(1), pp. 1-35. Available from:

http://journals.kent.ac.uk/index.php/feministsatlaw/article/view/7 [Accessed 12 February 2019].

Criales, L., and Condoreno, C., 2016. Breve reseña del taller de historia oral andina (THOA). Fuentes [online], 10(43), pp. 57-66. Available from: 
http://www.revistasbolivianas.org.bo/pdf/fdc/v10n43/v10n43 a12.pdf [Accessed 12 February 2019].

Dommann, M., 2008. Lost in tradition? Reconsidering the history of folklore and its legal protection since 1800. In: C.B. Graber and M. Burri-Nenova, eds., Intellectual Property and Traditional Cultural Expressions in a Digital Environment. Cheltenham: Edward Elgar, pp. 3-16.

Drahos, P., 1996. A Philosophy of Intellectual Property. Aldershot: Ashgate, pp. 13-39.

Esteva, G., 2015. Para sentipensar la comunalidad. Bajo el Volcán [online], 15(23), pp. 171-186. Available from: https://www.redalyc.org/pdf/286/28643473010.pdf [Accessed 12 February 2019].

Fitzpatrick, P., 1998. La mitología del derecho moderno. Ciudad de México: Siglo XXI.

Fitzpatrick, P., 2011. El derecho como resistencia: modernismo, imperialismo, legalismo. Bogotá: Siglo del Hombre / Universidad Libre.

Flores, B.G., 2016. Nos robaron a la novia: agravio y conflicto a raíz de la patrimonialización de la pirekua por la unesco. Sociológica [online], 31(87), pp. 175-206. Available from: http://www.redalyc.org/articulo.oa?id=305043762006 [Accessed 12 February 2019].

Graber, C.B., and Burri-Nenova, M., 2008. Intellectual Property and Traditional Cultural Expressions in a Digital Environment [online]. Cheltenham: Edward Elgar, pp. xixiii. Available from: https://doi.org/10.4337/9781848443914 [Accessed 12 February 2019].

Hagene, T., 2015. The Role and Style of Meetings in a Native Village in Mexico City: A Contribution towards the Analysis of Meetings. European Review of Latin American and Caribbean Studies [online], no 99, pp. 89-112. Available from: https://doi.org/10.18352/erlacs.10102 [Accessed 12 February 2019].

Hale, C.R., 2006. Activist Research v. Cultural Critique: Indigenous Land Rights and the Contradictions of Politically Engaged Anthropology. Cultural Anthropology [online], 21(1), pp. 96-120. Available from: https://doi.org/10.1525/can.2006.21.1.96 [Accessed 12 February 2019].

Hale, C.R., 2008. Introduction. In: C.R. Hale, ed., Engaging Contradictions: Theory, Politics, and Methods of Activist Scholarship. Berkeley: University of California, pp. 1-28. Available from: http://eprints.lse.ac.uk/42316/ [Accessed 12 February 2019].

Hale, C.R., and Stephen, L., eds., 2013. Otros saberes: Collaborative Research on Indigenous and Afro-Descendant Cultural Politics. Santa Fe: School for Advanced Research Press.

Hernández Castillo, A., 2016. Multiple InJustices: Indigenous Women, Law and Political Struggle in Latin America. Tucson: University of Arizona.

Ibarra, L., 2010. Autores Indígenas en México. Sortuz: Oñati Journal of Emergent Sociolegal Studies [online], 4(2), pp. 24-38. Available from: http://opo.iisj.net/index.php/sortuz/article/view/586 [Accessed 12 February 2019]. 
Ibarra, L., 2018. América Latina y la mirada socio-jurídica del Instituto Internacional de Sociología Jurídica de Oñati (IISJ). Oñati Socio-Legal Series [online], 8(5), pp. 586615. Available from: https://doi.org/10.35295/osls.iisl/0000-0000-0000-0967 [Accessed 12 February 2019].

Ibarra, L., et al., 2019. Community Administration as Cultural Policy: Empowering citizens in Eltzia. Oñati Socio-Legal Series [online], 10(1-this issue). Available from: https://doi.org/10.35295/osls.iisl/0000-0000-0000-1103 [Accessed 10 December 2019].

INAREMAC, 1985. 10 años de labores del INAREMAC: sus instrumentos de desarrollo alternativo. San Cristóbal: INAREMAC.

Jerónimo, J., 2017. La disputa por el derecho a la diferencia. In: F. Martínez et al., eds., Cherán K'eri: 5 años de autonomía [online]. Concejo Mayor de Gobierno Comunal de Cherán, pp. 135-141. Available from:

http://www.ceaal.org/v2/archivos/publicaciones/booksaf/Cheran5anivAutonomia .pdf [Accessed 12 February 2019].

Kongolo, T., 2008. Unsettled International Intellectual Property Issues. Alphen aan den Rijn: Kluwer Law International.

Kur, A., and Knaak, R., 2004. Protection of traditional names and designations. In: S. von Lewinski, ed., Indigenous Heritage and Intellectual Property: Genetic Resources, Traditional Knowledge and Folklore. Alphen aan den Rijn: Kluwer Law International, pp. 221-258.

Lemus, A., and Keyser, U., 2017. Introducción. In: C. Leco, A. Lemus and U. Keyser, eds., Juchari eratsikua, Cherán keri: retrospectiva histórica, territorio e identidad étnica. Concejo Mayor de Gobierno Comunal de Cherán, pp. 17-25.

Leyva, X., and Speed, S., 2008. Hacia la investigación descolonizada: Nuestra experiencia de co-labor. In: X. Leyva, A. Burguete and S. Speed, eds., Gobernar (en) la diversidad: experiencias indígenas desde América Latina: hacia la investigación de colabor [online]. Ciudad de México: CIESAS / FLACSO Ecuador / FLACSO Guatemala, pp. 34-59. Available from: http://www.flacsoandes.edu.ec/libros/112133-opac [Accessed 12 February 2019].

Lucas-Schloetter, A., 2004. Folklore. In: S. von Lewinski, ed., Indigenous Heritage and Intellectual Property: Genetic Resources, Traditional Knowledge and Folklore. Alphen aan den Rijn: Kluwer Law International, pp. 259-377.

Maldonado, B., 2015. Perspectivas de la comunalidad en los pueblos indígenas de Oaxaca. Bajo el Volcán [online], 15(23), pp. 151-169. Available from: http://www.redalyc.org/articulo.oa?id=28643473009 [Accessed 12 February 2019].

Martínez Luna, J., 2015. Conocimiento y comunalidad. Bajo el Volcán [online], 15(23), pp. 99-112. Available from: http://www.redalyc.org/pdf/286/28643473006.pdf [Accessed 12 February 2019].

Martínez Navarrete, E., 2017. ¡Bosque para quien lo trabaje! Relaciones de producción e identidad política en los procesos de autonomía indígena. El caso de Cheran K'eri. 
Ciudad de México: Centro de Investigaciones y Estudios Superiores en Antropología Social (CIESAS).

Matsui, K., 2015. Introduction to the Future of Traditional Knowledge Research. International Indigenous Policy Journal [online], 6(2). Available from: https://doi.org/10.18584/iipj.2015.6.2.1 [Accessed 12 February 2019].

Nader, L., 1990. Harmony Ideology: Justice and Control in a Zapotec Mountain Village. Redwood City: Stanford University Press.

Picciotto, S., and Campbell, D., 2003. Whose molecule is it anyway? Private and social perspectives on intellectual property. In: A. Hudson, ed., New Perspectives on Property Law, Obligations and Restitution. London: Cavendish, pp. 279-303.

Rivera Cusicanqui, S., 2012. Experiencias de montaje creativo: de la historia oral a la imagen en movimiento ¿Quién escribe la historia? Chasqui Revista Latinoamericana de Comunicación [online], $\mathrm{n}^{\mathrm{o}}$ 120, pp. 14-18. Available from: http://dx.doi.org/10.16921/chasqui.v0i120.495 [Accessed 12 February 2019].

Rivera Cusicanqui, S., and Lehm Ardaya, Z., 1988. Lxs Artesanxs Libertarixs y la Ética del Trabajo. La Paz: THOA.

Rivera-Lugo, C., 2014. ¡Ni una vida más para el derecho! Reflexiones sobre la crisis actual de la forma jurídica. Aguascalientes: Centro de Estudios Jurídicos y Sociales Mispat / Universidad Autónoma de San Luis Potosí.

Santillán, V.M., 2018. La sociedad de los comuneros: procesos políticos y relaciones de poder en Cherán, Michoacán. Ciudad de México: El Colegio de México.

Silva, E., 2017. Uso y costumbre*-cultura en palabra propia de Cherán K'eri. In: C. Leco, A. Lemus and U. Keyser, eds., Juchari eratsikua, Cherán keri: retrospectiva histórica, territorio e identidad étnica. Concejo Mayor de Gobierno Comunal de Cherán, pp. $31-43$.

South African San Institute, 2017. San Code of Research Ethics [online]. Northern Cape. Available from: http://trust-project.eu/wp-content/uploads/2017/03/San-Code-ofRESEARCH-Ethics-Booklet-final.pdf [Accessed 12 February 2019].

Speed, S., 2006. Entre la antropología y los derechos humanos: hacia una investigación activista y comprometida críticamente. Alteridades [online], 16(31), pp. 73-85. Available from: https://www.redalyc.org/pdf/747/74703107.pdf [Accessed 12 February 2019].

Teubner, G., and Fischer-Lescano, A., 2008. Cannibalizing epistemes: will modern law protect traditional cultural expressions. In: C.B. Graber and M. Burri-Nenova, eds., Intellectual Property and Traditional Cultural Expressions in a Digital Environment. Cheltenham: Edward Elgar, pp. 17-45.

Tobin, B., 2009. The role of customary law and practice in the protection of traditional knowledge related to biological diversity. In: C. Antons, ed., Traditional Knowledge, Traditional Cultural Expressions and Intellectual Property in the AsiaPacific Region: the International Debate about Traditional Knowledge and Approaches in the Asia-Pacific Region. Alphen aan den Rijn: Kluwer Law International, pp. 127156. 
Torres, Y., 2017. Participación del Concejo de Jóvenes. In: F. Martínez et al., eds., Cherán K'eri: 5 años de autonomía. Concejo Mayor de Gobierno Comunal de Cherán, pp. 121-123.

Velázquez, V.A., 2013. Reconstitución del territorio comunal: el movimiento étnico autonómico en San Francisco Cherán, Michoacán [online]. Tesis de Maestría en Antropología Social. Ciudad de México: Centro de Investigaciones y Estudios Superiores en Antropología Social. Available from: http://repositorio.ciesas.edu.mx//handle/123456789/230 [Accessed 12 February 2019].

Walsh, C., 2009. Interculturalidad, Estado, sociedad: luchas (de)coloniales de nuestra época. Quito: Universidad Andina Simón Bolívar / Abya-Yala. 